\title{
Publisher Correction: Identification of cell surface markers and establishment of monolayer differentiation to retinal pigment epithelial cells
}

\author{
Alvaro Plaza Reyes (D), Sandra Petrus-Reurer (D), Sara Padrell Sánchez, Pankaj Kumar (D), lyadh Douagi (D), \\ Hammurabi Bartuma, Monica Aronsson, Sofie Westman, Emma Lardner, Helder André (D), Anna Falk, \\ Emeline F. Nandrot (1), Anders Kvanta \& Fredrik Lanner (1)
}

Correction to: Nature Communications https://doi.org/10.1038/s41467-020-15326-5, published online 30 March 2020.

The original HTML and PDF versions of this Article were updated shortly after publication because the previous HTML and PDF versions incorrectly linked to an unrelated Transparent Peer Review file.

Published online: 06 May 2020

(c) (i) Open Access This article is licensed under a Creative Commons Attribution 4.0 International License, which permits use, sharing, adaptation, distribution and reproduction in any medium or format, as long as you give appropriate credit to the original author(s) and the source, provide a link to the Creative Commons license, and indicate if changes were made. The images or other third party material in this article are included in the article's Creative Commons license, unless indicated otherwise in a credit line to the material. If material is not included in the article's Creative Commons license and your intended use is not permitted by statutory regulation or exceeds the permitted use, you will need to obtain permission directly from the copyright holder. To view a copy of this license, visit http://creativecommons.org/licenses/by/4.0/.

(c) The Author(s) 2020 